\title{
K
}

\section{Kalīm Kāshānī}

Abū Ṭālib Kalīm Kāshānī (b. c. 9904/1582-6, d. 15 Dhū l-Hijja 1061/29 November 1651) was a Persian poet and an exponent of the Indian style (sabk-i hindi), which was ornate and rhetorical, with elaborate abstract figurative language.

Kalīm was born in Hamadān but soon moved to Kāshān, hence his nisbas Kāshānī and Hamadānī. He studied at Kāshān and Shiraz before going to the Deccan (c. 1010/1603) to seek his fortune at the Indian Mughal court. Although Kalīm did not enter the court, he became friends with Shāhnavāz Khān of Shiraz (d. 1020/1611), a court official under Ibrāhīm 'Ādil Shāh II (r. 9871035/1579-1626), the ruler of Bījāpūr (for the events of this troubled period, see 'Ābidī, Abū Ṭālib Kalīm Kāshānī, sharḥ, 209-10; Shiblī Nu'mānī, 173-4; Zafarī, 104-5). His first stay in India did not bring the success he had hoped for (Dìvān, ed. Qahrimān, 103-4). In 1028/1619 he returned to Persia, settling for two years at Isfahan, but won neither fame nor adequate recognition, as he complained in some of his poems.
He returned to India in 1030/1621 and was, until 1037/1628, at Agra in the service of the poet Mīr Muhammad Jumla Shahristān (pen name Rūḥ al-Amīn, d. 1047/1637), whom he addressed in several panegyrics. In 1037/1628, thanks to some encomia and chronograms, he joined the court of the Mughal emperor Shāh Jahān (r. 1037-68/1628-57). Kalīm won the favour of the sovereign and was given, in 1042/1632-3, the title of Malik al-Shu'arā (poet laureate). He was formally commissioned by Shāh Jahān to compose a poem immortalising the emperor's realm, and Kalimm dedicated the last years of his literary activity to composing a mathnavi (poem in rhyming couplets) titled Shäh-nāma ("The book of the king," having the same metre as Firdawsī's Shähnāma), also called Zafar-nāma-yi Shāh Fahānī ("The book of victory of Shāh Jahān"), Shāh-nāma-yi Kalīm ("The book of the king by Kalīm"), Shāh Fahān-nāma ("The book of Shāh Jahān"), or Pādshāh-nāma ("The book of the emperor"). His predecessor, Qudsī Mashhadī (d. 1056/1646), had composed a work on the same theme. In almost fifteen thousand lines, Kalīm's Shāh-nāma, still unpublished, narrates the most important events of Shāh Jahān's 
reign, from his birth to the tenth year of his reign. To devote himself to composing the mathnavi, Kalīm was given permission by the emperor to reside in Kashmir, a region of which the poet was particularly fond (Sharma, Kashmir). He continued to live in Kashmir until his death, in 1061/1651, and was buried there. Kalīm was the contemporary of many celebrated poets (for a complete list, see his Dìvān, ed. Qahrimān, sì-sì-u du), such as Salīm Ṭihrānī (d. 1057/1647), Qudsī Mashhadī (d. 1050/1640), Țālib Āmulī (d. 1036/1626-7), and Șāi ib Tabrīzī (d. 1087/1676-7).

Kalīm's poetical works amount to just over 24,000 lines, comprising around 15,000 couplets in the Shäh-nāma and 9,823 couplets collected in his Divān. The Dìvān, as edited by Qahrimān, contains thirty-six qașidas (panegyrics), two tarkībbands (stanzaic or strophic poems), one tarji-band (a poem with a refrain), thirtytwo qit'as (occasional poems), thirty-three tārikhs (chronograms), twenty-eight short mathnaviss, 590 ghazals (lyrics), and 102 rubāiss (quatrains).

Kalīm successfully used all the current poetic genres; his qașidas are considered very balanced, and his mathnavis are fluent and measured. He was skilled in constructing chronograms, but his fame is due mainly to his ghazals, and he is considered a master of that genre. Kalīm's ghazals, fairly regular in length, consist of an average of nine lines. Overall, his style is characterised by an incisive poetic creativity that accords with that of other poets writing in the same style.

Thanks to a powerful imagination, he expresses himself mainly in original metaphors, new similies, and refined fantastic aetiologies. The deliberate focus on creating new meanings - he was dubbed by the critic and biographer Muhammad Țāhir
Naṣrābādī (d. 1090/1679; p. 220) the Khallāq al-Ma'ānī-i Thānī (second creator of meanings), after the poet Kamāl al-Dīn Ismā'îl (d. c. 635/1237), from Isfahanwas often stressed by the poet himself, who claimed that it was unacceptable for him to re-use an image he had already elaborated, a practice he called theft (duzdī) (Dìvān, ed. Qahrimān, ghazal 535). His small poetic output (compared to the divanans of his contemporaries) confirms this quest for new themes rather than the re-elaboration of well known content. According to the critics, however, this experimentation is never to the detriment of his sincere expression and profound existential thought (Langarūdī, 122-5). His cultural and emotional integration into the Indian context is highlighted by his frequent use of Hindi words and by several poems expressing his fondness for that country.

Although assessments of his poetry were always conditioned by comparison with the works of Șāi ib Tabrīzī (d. between 1080/1669-70 and 1088/16778 , whose works the critics concur in judging superior), all the tadhkiras (collections of biographies) express positive opinions of his work - except for Ādhar Bīgdilī (d. 1194/1780), in his Ätishhkada-yi Ādhar ("Fire temple of Ādhar), pt. 2 (ed. Mīr Hāshim Muḥaddith, Tehran 1378sh/1999, 47-51), who always had a negative opinion of the poets of the Indian style (sabk-i hindī) - and the critics acknowledge his significant, original contribution to the development of the Indian style.

\section{BIBLIOGRAPHY}

\section{WORKS OF KALīM KĀSHĀNī}

For a survey of the first publications of Kalīm's works (except for his Shäh-nāma, which remains unpublished) and a list of manuscripts, see his Dìvān (ed. Qahrimān, 
pp. haftād-hashtād-u hasht); Aḥmad Munzavī, Fïhrist-i nuskhahā-yi khatți-yi fārsī (Tehran 1969-74), 3:1891, 2492-94, 4:2933; and Shams Langarūdī (108-16; see below). The first critical edition of his $D \bar{v} \bar{a} n$ is that by Muhammad Qahrimān (Dīvānn-i AbūTālib Kalìm-i Hamadān̄, Mashhad 1990), which includes a rich preface on the life and works of Kalīm, a critical apparatus with a description of the manuscripts and earlier editions, an appendix of supplementary critical texts, and a glossary of key terms, metaphors, compound words, idiomatic expressions and Hindi words. Other editions of his poetical works are: Bihtarīn äthār-i Kat̄̄m Kāshānn̄, ed. Muḥammad 'Alī Kishāvarz Șadr, Teh-

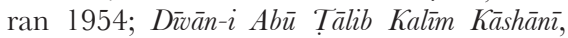
ed. Husayn Partaw Bayḍā̄ì, Tehran 1957; Dìvān-i Kalìm Kāshānī, with an introduction by Mihdī Afshār, Tehran 1983.

\section{STudies}

Amir Hasan 'Ābedi, Abū Ṭāleb Kalim Kāšāni, Indo Iranica 10/4 (1957), 25-40; Amīr Hasan 'Ābidī, Abū Ṭālib Kalīm Kāshānī, sharḥ-i hāal va āthār va sabk-i ash`ār-i ù, Bayādh 3/1 (1983), 197-333; Aziz Ahmad, Șafawid poets and India, Iran 14 (1976), 117-32, esp. 123; Sharīf al-Nisā' Baygam Anșārī, Hayāt va tașnifāt-i Mirzā Abū Țălib Kalìm Hamadān̄̄, Hyderabad 1961 (extensive monograph in Urdu); Edward Granville Browne, Literary history of Persia (London 1902-24), 4:25863; 'Alī Rị̣ā Dhakāvatī Qarāguzlū, Abū Ṭālib Kalīm. Shāirir-i hakīm va țanzāvar, Kayhān-i farhanḡ̄ 3 (1986), 29-32; Aḥmad Gulchīn-i Ma'ānī, Kārvān-i Hind, 2 vols. (Mashhad 1369sh/1990), 1175-87; Shams Langarūdī, Sabk-i Hind̄̄ va Kal̄̄m Kāshān̄̄, Tehran 1366sh/1987, 1372sh/19933 (an extensive critical study); Paul Losensky, "Square like a bubble." Architecture, power, and poetics in two inscriptions by Kalīm Kāshān̄̄, Gournal of Persianate Studies 8/1 (2015), 42-70; Muhammad Țāhir Nașrābādī, Tadhkira-yi Nașrābādì, ed. Hasan Vahīē Dastgirdī (Tehran n.d.), 220-3; Daryūsh Șabūr, Āfāq-i ghazal-i fārsī (Tehran 2535/1976, 1370sh/1991-2²), 449-51; Dhabīhallāh Șafā, Ganj-i suḳhan (Tehran 1984), 2:92-101; Dhabīballāh Șafā, Hamāsa sarāi dar Irān (Tehran 1333sh/1954, 1982), 372-3; Dhabīballāh Șafā, Tārīkh-i adabiyyāt dar İān (Tehran 1364sh/1986), 5/2:117081; S̄̄rūs Shamisā, Sayr-i ghazal dar shi'r-i fârsī
(Tehran 1362sh/1983, 19975), 174-5; Shiblī Nu'mānī, Shi'r al-'ajam, trans. from Urdu by Muhammad Taqī Fakhr Dā̄ì Gīlānī (Tehran 1316-27/1937-48, 1984²), 3:172-91; A. Rasūlī, Kalīm Kāshānī, Dānish-nāma-yi adab-i färsī (Tehran 2001), 4/3 (with extensive bibliography); Jan Rypka, History of Iranian literature (Dordrecht 1968), 301; Sunil Sharma, Mughal Arcadia. Persian literature in an Indian court, Cambridge MA 2017; Sunil Sharma, Kashmir and the Mughal fad of Persian pastoral poetry, in Borders. Itineraries on the edges of Iran, ed. Stefano Pellò (Venice 2016), 183-202; Sunil Sharma, Val̄̄ Allāh Zafarī, Habsiyya "Zindān-nāma" dar adab-i färsì (Tehran 1985), 104-5; Riccardo Zipoli, Il marchio rovente. Dājg in Katìm e 'Urfi, Venice 1983.

Daniela Meneghini

\section{al-Kalwadhānī, Abū l-Khaț̣āb}

Abū 1-Khațțāb Maḥfūẓ b. Aḥmad b. al-Ḥasan al-Kalwadhān̄i (2 Shawwāl 432-23 Jumādā II 510/5 June 1041-2 November 1116) was a Hanbalī jurist and one of the most important early authorities of the Hanbali legal school. He apparently spent his life in Baghdad and was a student of the renowned Hanbalī judge Abū Ya lā Ibn al-Farrā' (d. 458/1066), with whom he studied the majority opinions of Hanbali jurisprudence (almadhhab), legal theory, and disputed legal points (khilāf). He was also an authority on inheritance law, which he studied with the jurist Abū 'Abdallāh al-Husayn b. Muhammad al-Wann̄̄ (d. 450/1058); and on hadith, the collected sayings and precedents of the prophet Muhammad. He was additionally a respected littérateur (adīb) and poet. The biographers Ibn Rajab (d. 795/1392), al-Dhahabī (d. 748/1348), and Mujīr al-Dīn al'Ulaymī (d. 928/1522) have preserved several of his shorter poems (maqtūi $\bar{a} t)$. 